\title{
The Double-entry Bookkeeping Committee of 1914 and the Brazilian Public Accounting System
}

\author{
Tiago Villac Adde \\ Master's Degree in Accounting and Actuarial Sciences, Pontifical Catholic University of São Paulo \\ E-mail: villac@uol.com.br \\ Sérgio de ludícibus \\ PhD., Professor, Department of Accounting and Actuarial Sciences, Pontifical Catholic University of São Paulo \\ E-mail: siudicibus@yahoo.com.br \\ Álvaro Augusto Ricardino Filho \\ PhD., Professor, Department of Accounting Sciences, Pontifical Catholic University of São Paulo \\ E-mail: aricardinofilho@gmail.com

\section{Eliseu Martins} \\ PhD., Senior Professor, Department of Accounting, University of São Paulo \\ E-mail: emartins@usp.br
}

Received on 10.30.2013 - Desk Acceptance on 11.07.2013- $3^{\text {rd }}$ version accepted on 07.17.2014

\begin{abstract}
The history of Brazilian accounting has not been explored at length. Through a historical survey, this article presents the history of the Double-entry Bookkeeping Committee of 1914. After the Proclamation of the Republic was announced in 1889, the government started to expand its administrative bodies, necessitating the introduction of a bureaucracy able to perform new functions. In the same period, Brazil experienced a strong economic development with the development of its coffee industry. In 1905, under the leadership of Carlos de Carvalho, São Paulo State Treasury bookkeeping tasks were introduced under a double-entry bookkeeping system and through accrual and financial accounting. Double-entry bookkeeping practices in the federal public accounting system, although enshrined in law since 1808, were only fully realized after the creation of the Double-entry Bookkeeping Committee in 1914. In that same year, due to the negotiation of a second funding loan, English creditor bank auditors requested a balance of the National Treasury from the Minister of Finance Rivadávia Corrêa. Because the balance had not been prepared in eight years, the Double-entry Bookkeeping Committee was established in June of 1914, and this body completed a technical audit of Revenues and Expenditures. The committee also conducted the state administration's first Asset and Liability audit since the colonial era. The Double-entry Bookkeeping Committee of 1914 spearheaded changes to the Brazilian public accounting system, including the creation of the Public Accounting Code in 1922 and the approval of Central Accounting Office of the Republic regulation in 1924, strengthening and ascribing perpetuity to practices adopted after 1914.
\end{abstract}

Keywords: Public accounting. Double-entry bookkeeping. Double-entry Bookkeeping Committee. 


\section{INTRODUCTION}

By June of 2014, a century had passed since the previous Minister of Finance, Rivadávia Correa, introduced the Double-entry Bookkeeping Committee under the administration of President Hermes da Fonseca. The event was of unique importance to the double-entry bookkeeping system's (DEB) definitive introduction into Brazilian public accounting, and this event thus warrants recounting.

A review of the few works published on this topic reveals that the history of Brazilian accounting has not been explored at length. D'Auria (1925, p.25) asserts that "Brazil could be portrayed honorably based on its accounting history. Little, or virtually nothing, has been written on this matter in our country." According to Martins, Silva, and Ricardino Filho (2006), the lack of research focused on the recovery of Brazilian accounting history has allowed certain statements to perpetuate through continuous written or verbal references to the original statement.

In studying this facet of Brazilian accounting history, this article attempts, albeit minimally, to address this knowledge gap. Accordingly, we seek to recount the history of the Double-entry Bookkeeping Committee's creation in 1914, thus increasing the scope of literature available on the adoption of DEB in national public accounting and possibly inspiring additional studies on the history of Brazilian accounting. The study also analyzes the committee's role as a catalyst of federal accounting changes adopted during this period. The study examines events that occurred in the years preceding the establishment of the Double-entry Bookkeeping Committee in 1914 (primarily after 1889) and the committee's influence on events that occurred following its creation until the late 1920s.

Historical research methods were applied to fulfill these research objectives. According to Aróstegui (2006), historical research, if understood as a survey of the past, includes unique features that are not present, or which are not presented in the same manner, in other social sciences. The method is first unique in that it involves the examination of indirect information sources that are based on vestiges, remains and testimonies, which are informative materials that are typically used by historians. The method is also unique in its focus on time. Rather, historical research and representation involves not only the recounting of forgotten events but also understanding how societies behave and evolve over time. The third unique feature of historical research concerns the global historical process, as a societal history is typically interwoven with the histories of all societies worldwide.
Qualitative techniques were applied in this study. According to Aróstegui (2006), qualitative techniques do not involve database construction measurements. Instead, these methods involve classifying, typifying, and gathering data based on qualities and characteristics (which requires the researcher to first conceptualize tasks) and classifying phenomena based on verbal information or verbalized numerical information. Qualitative techniques always terminate in verbal information. In this study, the documentary observation qualitative technique, which involves examining primary and secondary sources, was used.

Of the primary sources examined in this study, the Cinqüenta Anos de Contabilidade (1903-1953) (Fifty Years of Accounting (1903-1953)) autobiographical piece by Francisco D'Auria was focused on at length. This work provides a detailed account of the professional life of the author, who was a member of the Double-entry Bookkeeping Committee of 1914 and the Accountant General of the Republic of Brazil from 1923-1928 (D’Auria, 1953). Iudícibus (2010) asserts that the most prominent Brazilian authors of the classical school were Francisco D’Auria and Frederico Herrmann Júnior. D'Auria is considered to have been the most "Brazilian" of the famous authors of the time in that he formed what may be called the foundation of an authentic Brazilian School of Accounting.

Other relevant primary sources examined included works written by João Ferreira de Moraes Junior, who was also a member of the Committee, and Carlos de Carvalho. The Revista Brasileira de Contabilidade (Brazilian Journal of Accounting) and Revista Paulista de Contabilidade (São Paulo Journal of Accounting) periodicals, newspaper and legislative documents of the period, and Brazilian historical, economic and accounting history works were consulted.

The article is organized as follows. The following section presents recent academic approaches to the study of accounting history and the design adopted in this study. This is followed by a description of the Brazilian public accounting system in place in the political and economic context of the Proclamation of the Republic (1889). The subsequent funding loan episode, the creation of the Double-entry Bookkeeping Committee of 1914, and comments on the DEB of Brazilian legislation are presented. Finally, we describe the development of federal public accounting after the committee's establishment and close with a series of conclusions.

\section{DEVELOPMENT}

Accounting history research has evolved over the last quarter of the $20^{\text {th }}$ century, and on the international sca- le in particular. This evolution has been accompanied by changes in theoretical research approaches. According to 
Edwards, Coombs, and Greener (2002), accounting historians, particularly the traditional, have been criticized for depicting accounting history as a continually evolving process of technical development and improvement. This approach to historical accounting research was criticized in 1987 by Anthony Hopwood, a leading architect of the so-called "New Accounting History" movement. Hopwood argued that most previous accounting history studies had adopted a rather technical perspective, outlining the residual impacts of accounting events rather than more actively investigating underlying processes and forces at work.

According to Miller (1994), a profound transformation in the understanding of accounting has occurred since the 1980s. Accounting has come to be regarded as a social and institutional practice, one that is intrinsic to and constitutive of social relations, rather than derivative or secondary. A focus has been placed on accounting as a practice, a view that accounting is, above all, an attempt to intervene, to act upon individuals, entities and processes to transform them for specific purposes. According to this perspective, accounting can be understood as a set of practices that shape the environments and social realities that we occupy, the way in which we understand the choices available to companies and individuals, the way we manage and organize activities and processes, and the way we manage others and ourselves.

Carnegie and Napier (2002) identify an emergence of studies focusing on the history of public sector accounting in several countries. Because public sector organizations are often more likely to survive than private sector entities and because these organizations generally adopt more formal approaches to records management, the public sector typically offers an abundance of primary research materials. Recent studies focusing on public sector accounting practices include works by Edwards et al. (2002) and Edwards and Greener (2003), who examined the British central government's adoption of the DEB. Gomes, Carnegie, and Rodrigues (2008) examined DEB adoption in the context of the Portuguese Royal Treasury.

According to Gomes et al. (2008), from the 16th to the 19th century, various European governments implemented accounting reforms that involved the introduction of DEB approaches for central government public finance management. The success of previous applications of DEB for commercial purposes, and especially by large commercial establishments, convinced decision makers of the technique's potential utility for public administration. According to Carvalho (1914), public accounting systems in England, France, Italy, Spain, Belgium and Argentina had adopted DEB approaches by the early 20 th century.

The present study describes the achievements of the Double-entry Bookkeeping Committee of 1914 and the ways in which this committee spurred changes in the Brazilian public accounting after its creation.

\subsection{Public Accounting in the Political and Economic Context of the Proclamation of the Republic (1889).}

The introduction of the Proclamation of the Republic of 1889 was followed by nearly a decade of political disruptions, which resolved only under the direction of President Campos Sales with the establishment of the Policy of the Governors. This policy remained in effect, though not without disturbances, until its final rupture in 1930 with the start of the Revolution of 1930 and with the fall of the First Republic.

According to Prado Júnior (1994), the Republic, which abandoned the Empire's conservative framework despite all of its concessions, triggered the rise of a new spirit and social tone that better reflected the phase of material prosperity that the country was entering. Considerable economic growth occurred during this period, and especially in the realm of foreign trade, which was largely financed through international capital and credit. In addition to coffee, other products such as rubber (which would later become as nearly prominent as coffee), cocoa, mate and tobacco became major export materials. Brazil emerged as one of the major world producers of raw materials and tropical products during this period.

According to Saes and Cytrynowicz (2001), during the second half of the 19th century, the growth of the coffee industry, the introduction of Commercial Code, and the establishment of railways and urban service companies through domestic and foreign investment are indications of the economy's increasing complexity. Given this context, more thorough knowledge of trade and business management principles became imperative, and this became even more apparent from the start of the First Republic. The economic growth of domestic coffee production (despite recurring crises) continued, accelerating urbanization processes. Concurrently, large industries were established, and the number of import and export trade houses, banks and companies continued to multiply. Importantly, the abolition of slavery, the rise of intensified immigration trends and the introduction of free and wage form of labor also characterized this period.

According to the same authors, in this economic context, the management of productive activities and the delivery of administrative control over flows of goods and capital grew more imperative, requiring qualified individuals who could exercise these tasks. The republican government system itself also grew during this period, expanding its increasingly specialized administrative bodies and thus requiring the institution of a bureaucratic staff able to support these functions. Finally, urbanization processes increased the size of the middle class, which, without access to traditional higher education resources (Law, Medicine and Engineering), longed for professional training that facilitated social ascent.

The transformation of the Brazilian economy during this period was reflected in all realms of society, including the accounting professionals, who were commonly referred 
to as Bookkeepers. Their official representation by a professional association was obtained in 1870 , when Decree no. 4,475, signed on February 18, 1870, approved the statutes of the Association of Bookkeepers.

During the early twentieth century, a new impetus is given in the establishment of business schools that were primarily dedicated to accountant training. In 1902, the Rio de Janeiro Commerce Academy (Academia de Comércio do Rio de Janeiro) and the São Paulo Practical School of Commerce, later called the Álvares Penteado School of Commerce (Escola de Comércio Álvares Penteado) were founded (Saes \& Cytrynowicz, 2001). In 1905, the Commercial School of Bahia (Escola Comercial da Bahia) was founded, and in subsequent years, several other schools were established (Sá, 2008).

Legislative Decree no. 1,339 of January 9, 1905 declared the Rio de Janeiro Commerce Academy a public utility institution and recognized the school's diplomas as official credentials. The decree extended the same provisions to the Álvares
Penteado School of Commerce. In subsequent years, the provisions of this decree were extended to several other schools.

With the establishment of the Republic, several normative acts $^{1}$ were established to reorganize federal public administration services, and specifically those provided through the Federal Treasury and the Ministry of Finance Board of Accounting. Concerning the remodeling of Brazilian public accounting, an emphasis must be made to the modernization of commercial bookkeeping in 1905 by the State of São Paulo government. According to D’Auria (1953), Decree no. 1,335 of December 12, 1905 enacted by the State of São Paulo government dramatically improved financial administration practices conducted in São Paulo, in Federal government departments and across the entire country. As shown in Figure 1, the $1^{\text {st }}$ Article of the decree states, "Commercial bookkeeping is hereby established in the State Treasury," and the $4^{\text {th }}$ Article states, "The bookkeeping practices described in this decree will be instituted on January 1 $1^{\text {st }}, 1906$ ” (D’Auria, 1953, p.16).

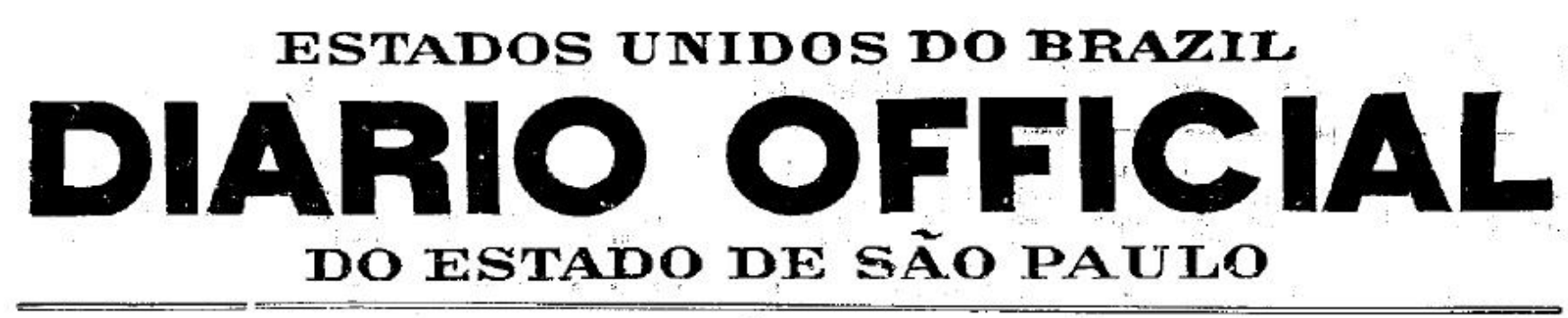

\begin{tabular}{|c|c|}
\hline ANNO $15.0^{\circ}-180^{\circ}$ DA RiBPUBLica - N. 274 & QuiNTA-FEIRA, 14 DE DezRMisRo DE 1906 \\
\hline 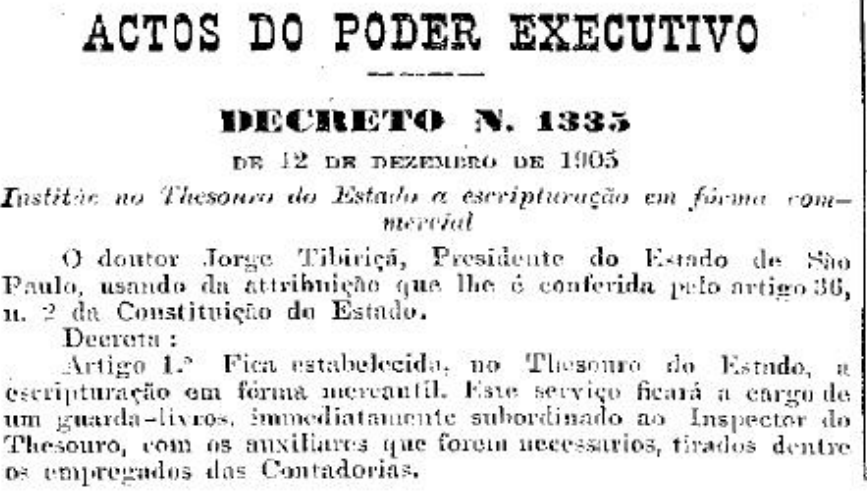 & 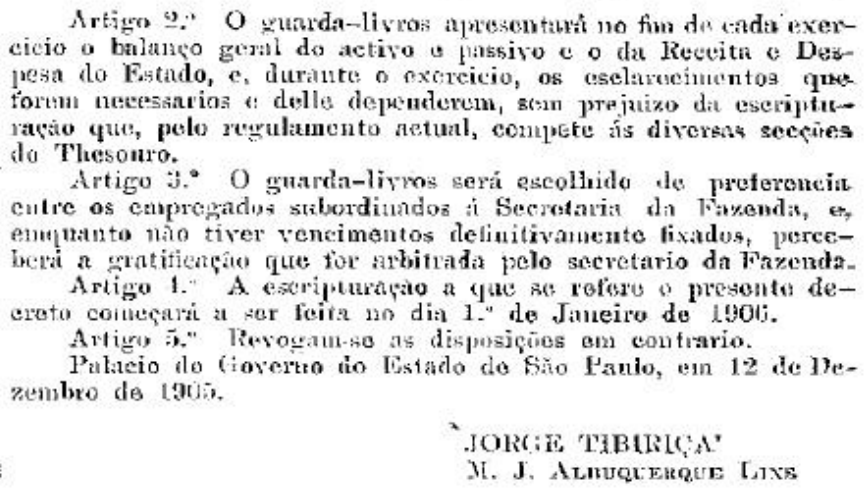 \\
\hline
\end{tabular}

Figure 1 Decree no. 1,335 of December 12, 1905. Sets the commercial bookkeeping in the State Treasury. Diario Official do Estado de São Paulo. December 14th. Retrieved from http://dobuscadireta.imprensaoficial.com.br/default.asp x?DataPublicacao=19051214\&Caderno=Diario\%20Oficial \&NumeroPagina=3039.

According to Mascarenhas (1922), in 1905, the state of São Paulo was involved in two large projects: the expropriation of the Sorocabana Railroad and the appreciation of coffee via the Taubaté Agreement. Owing to his expertise in this area, Carlos de Carvalho was invited to manage these two operations in minute detail and to also reform Treasury bookkeeping practices through the establishment of DEB and the introduction of accrual accounting in conjunction with financial accounting. According to Mancini (1978), in 1892, Carlos de Carvalho was held responsible for organizing the accounting system of the São Carlos municipal government, with guidance of the Polish Estanislau Kruszynski.
D’Auria (1953) asserts that the most pivotal moment in Brazilian public accounting history of that time occurred when Carlos de Carvalho presented his approach to the State of São Paulo Treasury. Carvalho opens Chapter 3 (Assets and Liabilities of the State) of his Report to the Department of Finance of 1905 with the following statement: "For the first time, the Treasury of the State of São Paulo presents an audit of assets and liabilities that is complete and organized according to rules devised by public accounting experts" (D'Auria, 1953, p.17). The bookkeeping method adopted by the State of São Paulo was later adopted by federal accounting departments and by several other state and municipal governments throughout the country. 


\subsection{The Second Funding Loan and the Creation} of the Double-entry Bookkeeping Committee.

The funding loan, a loan designed to restructure foreign debt, was first completed in Brazil in 1898. Brazilian foreign debt renegotiation was facilitated as part of the program for national finance restoration promoted by president Campos Sales. Though characterized by austerity, the program was pivotal to the maintenance of economic stability in the following decade.

According to Fausto (1977), the first outcomes of the coffee appreciation policy, which was instituted under the 1906 Taubaté Agreement, became evident in 1909. International coffee prices rose and remained high until 1912 due to supply retraction and a reduction in crop volumes. Trends of economic recovery accelerated from 1903 with the introduction of public investment programs by the government of President Rodrigues Alves, which particularly focused on refitting ports while extending and equipping the rail network.

However, according to Abreu (2002), rising foreign debt trends rendered the Brazilian economy extremely vulnerable to capital and export flow disturbances. From 1912, Brazil faced a series of events that radically transformed the country's balance of payments. Debt services resulting from the first funding loan had resumed since 1909. Coffee exports declined with a fall in prices that occurred due to the sale of American stocks after the establishment of the Sherman $\mathrm{Act}^{2}$ by the American justice system. Rubber exports declined dramatically with the introduction of Asian rubber to the world market. It grew increasingly difficult to post Brazilian loans with processes of political deterioration occurring in Europe and especially in the Balkans.

Fausto (1977) notes that in 1913 export product prices fell dramatically while the maintenance of the high-volume imports produced a deficit in the Brazilian trade balance for the first time in the history of the Republic. With the outbreak of World War I in July of 1914, foreign capital inflows were paralyzed, and the country was forced to pay 10 million pounds to meet foreign debt commitments. In August of 1914, the free market exchange rate fell below the stabilization rate, triggering a run on Conversion Bank (Caixa de Conversão) ${ }^{3}$ deposits and the bank's closure.

Consequently, the negotiation of a second funding loan became inevitable. According to Fritsch (1988), in September of 1913, British Rothschild bankers were sent to Rio de Janeiro on a financial mission ${ }^{4}$ to evaluate Brazil's ability to service foreign debt and to support the negotiation of a new major public loan. Indirect evidence shows that the bankers were not optimistic about what they saw, suggesting that if financial assistance were to be provided, it would be delivered on strict conditions. In March of 1914, the last year of the presidential term of Hermes da Fonseca with Rivadávia
Correa as minister of finance, a conference of bankers led by N.M. Rothschild \& Sons Limited that included major French banks as well as Speyer and Schroeder decided that it was impossible to determine the terms of a loan to Brazil without additional information (Abreu, 2002).

According to D'Auria (1953), the bankers requested information on the Treasury balance. English bank representatives who were to provide the loan ${ }^{5}$ requested that minister Rivadávia Corrêa provide them with a demonstrated statement of the Republic's financial situation. The minister then instructed the accounting director to present the balance of the Treasury. To the disappointment of minister Corrêa, the balance had not been prepared for eight years, with the last balance sheet having been published in 1905. The minister then directed Carlos Claudio da Silva, accounting director of the Conversion Bank, and Francisco Chagas Galvão, accounting sub-director of the National Treasury, to initiate immediate calculations for the regularization of Treasury balances. Both of these men concluded that accounting protocols followed at the State of São Paulo Treasury should be examined and that the National Treasury should adopt procedures followed at this department.

Statements previously prepared by the National Treasury were in complete noncompliance with the most trivial precepts of public accounting, presenting mere figures on revenues and expenses. Rui Barbosa, the then Minister of Finance of the Provisional Government, asserted that the practices and theoretical underpinnings of the Brazilian public accounting system were outdated (Contabilidade Fiscal, 1916).

A committee of the federal government met with Carlos de Carvalho, chief of the Accounting Section of the Department of Finance, in São Paulo. According to D'Auria (1953), Carlos de Carvalho, with a "sharp astuteness" that characterized his disposition, soon realized that no member of the federal committee could establish the accounting organization practiced by the government of São Paulo. He thus persuaded the committee that the most effective means of reforming federal accounting would involve sending two of his assistants, Francisco D’Auria and Carlos Levy Magano, to Rio de Janeiro. By means of an act installed by minister Corrêa, the "Double-entry Bookkeeping Committee" headed by Carlos Claudio da Silva was established in June of 1914, and the committee officially began operations on June 16, 1914 (Lobo \& Moraes Junior, 1941). João Ferreira de Moraes Junior and Ernesto Le Cesne were also appointed to the committee.

The committee's first task involved gathering data to open the balance sheet. The first remodeling stage was completed after six months when, according to D'Auria (1953), the Revenue and Expenditure audit and the first Asset and Liability audit prepared in the country since

Federal legislation of 1890, which forbade the creation of monopolies, curbed direct or indirect attempts to interfere with the free and competitive nature of the production and distribution of goods.

The Conversion Bank created in 1906 aimed at maintaining exchange rate stability by fixing the nominal exchange rate.

To draw a comparison, such financial missions were similar to those carried out by the International Monetary Fund (IMF).

According to Abreu (2002), negotiations on the second funding loan continued for months and were suspended with the advent of World War l. In September of 1914, it was agreed that the funding loan would reach a maximum nominal capital value of 15 million pounds, an amortization period of 63 years with redemption starting from 1927, guaranteed by Rio de Janeiro customs revenues and, secondarily, all other Republic customs. All repayments of federal loans denominated in pounds or French francs would be suspended until August 1, 1927, and loan interest that expired between August 1, 1914, and July 31, 1917 was refinanced with new titles. The issuance and guarantee of new foreign loans or domestic loans with interest payable abroad was also prohibited for three years. 
colonial times were conducted in a technical manner. By the end of 1914, the Report of the Double-entry Bookkeeping Committee was drafted, and the two aforementioned balances were attached ${ }^{6}$. The report was presented to the then president of the Republic, Venceslau Brás. During the presentation, Francisco D'Auria stressed to the president that while the balances were technically accurate, they contained incomplete data due to delays in the provision of data by tax offices and Treasury pay-offices. The president then instigated immediate actions to resolve these pending issues.

During this meeting, Francisco D'Auria was also given the opportunity to describe the principle of accrual to the president. D'Auria reported that the Brazilian Revenue and Expenditure balance sheet did not fully reflect the financial situation at the time, as it did not include expenses that had been incurred but which were not yet paid. The president argued that it should not be otherwise, as expenses not yet paid should not be included in the balance. In response, D'Auria argued that this approach is technically inaccurate and politically inconvenient, as the omission could allow the postponement of payments in order to simulate a better financial picture (D’Auria, 1953).

Senator João de Lyra Tavares, a previous member of the Double-entry Bookkeeping Committee prior to his election to the Senate, referred to works generated by this committee in a speech to the Senate on November 17, 1915:

I assert to the Senate with the responsibility of a humble professional that the work done by the committee is of utmost importance, and I was pleased to hear from the current Minister of Finance, Mr. Dr. Pandiá Calógeras, that the double-entry bookkeeping system will be implemented in finance offices next January. Therefore, it is left to us to immediately pass the public accounting code $^{7}$, whose draft is managed under the Chamber of Deputies (D’Auria, 1953, p.44).

D'Auria (1953) asserts that the good standing of the Double-entry Bookkeeping Committee was largely attributable to the efforts of João Pandiá Calógeras, Minister of Finance of the government of President Venceslau Brás from July of 1915 to September of 1917. Through an Ordinance of Minister Calógeras, the "Double-entry Bookkeeping Section" was created on December 31, 1915 , and this event, according to the author, was an influential initial step towards ensuring federal accounting system reform.

There was opposition to the implementation of Double-entry Bookkeeping Committee protocols and even from members of the Ministry of Finance. According to D'Auria (1953, p.42): “Opposition to our services first came from the highest officials of the Ministry - the bishops of the division, as they were then called." According to Carvalho (1914), press content also revealed resistance to the adoption of DEB by the National Treasury.

DEB implementation in tax offices began in the Fiscal Office of São Paulo in September of 1916. According to D'Auria (1953), the approach was then extended to similar offices.

\subsection{Comments on DEB in Brazilian Legislation.}

The DEB system of national public accounting, whose adoption was proclaimed and implemented by the federal government in 1914, had been referenced in legislation since 1808 through the Charter of June 28, 1808, of D. João VI, who created the Royal Treasury and the Board of Finance ${ }^{8}$. The July 22, 1914 O Estado de S. Paulo newspaper issue, which republished an editorial of the newspaper Correio da Manhã, quipped about the situation:

- Regarding the introduction of the double-entry bookkeeping system in public offices:

The establishment of the double-entry bookkeeping system for all public offices is "now" being talked about.

There is no need to say that this is the system used in almost all the civilized world. However, there is a need to add that what is "now" planned does not constitute any news for Brazil.

On June 28, 1808, therefore shortly after the arrival in Rio de Janeiro of King d. João VI, a "Charter" was published, which is transcribed below, not as historical remembrance, but as an affirmation that in Brazil there is no lack of wise laws to govern it, but there has been unawareness of the existence of these laws, which, for this reason, have not been put into force.

The "Charter" is transcribed, which seems to have been written on purpose to be read in these current times:

"Creation of an Exchequer or a General and Public Treasury. Title II - On the bookkeeping method and accounting of the Exchequer.

1st- For the bookkeeping method and accounting formulas of my royal Finance not to be arbitrary, and subject to the way of thinking of each of the Accountants general I am served, to create for the Exchequer referenced: I command that the bookkeeping is double-entry mercantile, for it is the single method followed by the civilized nations, and also for of its brevity for the management of large sums, for it is the clearest method, and the one that least provides errors and subterfuges, where the malice and the fraud of prevaricators hide.

2nd - Therefore, there will be in each of the General Accounting Offices one bookkeeper's journal, one master-book, one memorial or blotter, in addition to one auxiliary ledger or of current accounts for each of the revenues of collection stations, excise offices, treasuries, contracts or administrations of my Royal Finance. And this to see wi- 
thout delay, as soon as needed, the account status of each of the debtors or exactors of the rents of my crown and public funds.

3rd - I order that these bookkeeping journals are inalterable and that for this purpose none can be increased or diminished, without making me aware by consulting the president, the need for increasing or diminishing their number" (Jornaes do Rio, 1914, p.5).

D’Auria (1925, p 25) also comments on these issues:

A diligent student of accounting matters, the illustrious Dr. Viçoso Jardim, produced a "Historical Synthesis of Public Accounting in Brazil" in his substantial work "Public Accounting in Brazil" Dr. Viçoso Jardim cites legislation related to the Royal Treasury from its first act, the charter of June 28, 1808. According to this legislation, the practice of effective accounting was not neglected at that time.

The cited author speaks of the remarkable Accountant General Manoel Alves Branco, a highly dedicated employee that was later elevated to the post of Minister of Finance.

The instructions of April 26, $1832^{9}$ include appropriate double-entry bookkeeping norms. Though it does not present a complete accounting method, it denotes the occurrence of notable progress at the time it was practiced. The fact that such a well-intentioned seed has not sprouted is sad and even humiliating. While Treasury regulations always prescribed the use of double-entry bookkeeping, in reality, these regulations are only referenced because Treasury bookkeeping, prior to its recent reorganization, had always represented a lamentable attestation of the carelessness of a major service provided to the administration of public money.

In a Revista Brasileira de Contabilidade [Brazilian Journal of Accounting] article entitled "The Public Accounting Law Still," João Ferreira de Moraes Junior describes the history of DEB use in Brazilian public accounting. According to Moraes Junior (1921a), the misinterpretation of Decree no. 5,245 of April 5, 1873, which abolished the rewriting of Bookkeeper's Journals and Master-Books, drew an incorrect assumption that the DEB had been abandoned ${ }^{10}$. The author asserts that for over a century, the DEB mandate had been included in Finance legislation and that it was arbitrarily dropped after being practiced for over a certain period.

According to Moraes Junior (1921b), the main factors that hindered the efficiency of DEB in public accounting were Inertia, Incompetence and Unwillingness. Inertia prevented the method from being put into practice despite the fact that it was a law to be followed. Incompetence prevented influential individuals from understanding the benefits of double-entry bookkeeping. Finally, Unwillingness prevented the method's implementation due to its labor-intensive nature, requiring extensive booking and financial resources, a special body of technicians for its implementation, and adherence to meticulous, demanding and indiscreet practices that would create difficulties for the administration.

Gomes et al. (2008) note that studies of European central government accounting reforms also show that the initial adoption of DEB by central governments was not straightforward in some countries. Associated with the generally slow process of DEB adoption was typically a lack of qualified professionals who held knowledge and experience in DEB, and this affected the system's implementation.

\subsection{Developments in Federal Public Accounting after the Establishment of the Double-entry Bookkeeping Committee of 1914.}

One of the first amendments made to federal legislation after the Double-entry Bookkeeping Committee of 1914 was introduced through the publication of Decree no. 13,248 of October 23, 1918 by the then Minister of Finance Antônio Carlos Ribeiro de Andrada. This decree amended Decree no. 7,751 of December 23, 1909, which concerns the General Administration of National Finance service regulation. More specifically, the competence of the Board of Accounting of the National Treasury in its supreme administration of federal government accounting was reinforced, and ministry accounting boards and sections, regardless of their denominations, treasuries and pay-offices and irrespective of whether they performed civilian or military functions, were included as part of its body.

An important modification made to Article 45 of this Decree created the Accounting Section. According to Moraes Junior (1921b), the final installment of the Double-entry Bookkeeping Committee of 1914 as a technical body of the Board of Accounting occurred with the creation of this section. The Accounting Section was mainly ascribed the task of performing Revenue and Expenditure bookkeeping tasks for the federal government through the double-entry bookkeeping system. On September 3, 1919, Decree no. 13,746 provided general guidelines on public accounting.

Lobo and Moraes Junior (1941) note that while these legal arrangements existed, the DEB was still difficult to implement, especially in tax and customs offices across the country. While instructors were sent to state governments to introduce the double-entry bookkeeping system to tax and customs offices, in several cases, these efforts were wasted as staff employed in these offices often moved. Rather, employees who started to become competent in the system methods left bookkeeping departments either by their own volition or for the convenience of tax officers and inspectors, some of them very keen in demonstrating that the newly adopted method 
was unenforceable. Despite the delivery of specific instructions and models through Decree no. 13,746, most offices were late to deliver monthly and definitive balance sheets, which were the main instruments of accountability and centralization. An autonomous agency designed to oversee public accounting throughout Brazil was needed.

According to D'Auria (1953), after several years, the draft of the Public Accounting Code was still being developed by the Committee of the Federal Chamber. Motivations to reform National Treasury accounting practices from mid-1914 spurred the development of works by this committee. The draft was presented in 1917 by congressman Barbosa Lima.

On January 28, 1922, through Legislative Decree no. 4,536, the Accounting Code of the Federal Government was established. The decree was divided into six chapters: Centralization of Accounting Services; Financial Period Budget and Financial Management Accounts; Public Revenue; Public Expenditure; Public Assets; and Those Responsible for Public Assets.

The code provided through the Federal Government Accounting division included all acts related to national patrimony management accounts. It also accounted for the inspection and recording of federal revenues and expenses housed under the Ministry of Finance under the immediate direction of Central Board of Accountancy of the Republic ${ }^{11}$ and the Court of Auditors. According to D'Auria (1953), Accounting Code regulations composed of about 900 articles installed through Decree no. 15,783 of November 8, 1922 were prepared by João Ferreira de Moraes Junior.

Lobo and Moraes Junior (1941) assert that the appearance of the Accounting Code after such a long period of stagnation in Congress was also inspired by government, deputy and senator motivations to introduce order to Federal Government accounts. The same authors also stress the importance of unacknowledged and anonymous work conducted by individuals devoted to the cause of public accounting in Brazil, who began to convince the most influential legislators that the code in question was imperative.

The Central Accounting Office of the Republic was created via Decree no. 15,210 of December 28, 1921. However, through Decree no. 16,650 of October 22, 1924, the Central Accounting Office of the Republic was decisively organized, and its rules were approved.

According to Decree no. 16,650, the Central Accounting Office of the Republic would be managed by the Ministry of Finance and not by the National Treasury. As a centralized accounting body of the Federal Government, the department was responsible for all actions related to management accounts related to national patrimony, the inspection and recording of federal revenues and expenditures and the overseeing of accounting of all federal agencies and services, either military or civilian. Besides the supreme administration of the Federal Government general accounting, the Central Accounting Office was res- ponsible for overseeing the faithful compliance of federal departments and services, either civilian or military, based on public accounting precepts established through the Accounting Code and its regulations.

Accounting offices and sectional sub-offices across the country were subordinate to the Central Accounting Office of the Republic. The Accounting Office would operate ongoing inspection services in all subordinate departments. The accountant general, accountant adjunct, sub-accountants, section chief secretary, bookkeepers and assistants would be appointed via the decree of the president. Moraes Junior (1921b) comments on this body:

In the speech were the Special Committee opinions on amendments presented in the third discussion of the Code [of Public Accounting] are justified, the illustrious Congressman Dr. Josino Araujo praises the creation of an Accounting Office that "is primarily aimed at systematizing, organizing, managing, guiding and supervising all services of ministry accounting and those of other dependent offices" and states that the centralization and standardization of laws and accounting precepts "shall form the cerebral-spinal center of the nervous system, guiding all movements of the body" (Moraes Junior, 1921b, p.103).

According to D'Auria (1953), the creation of a body such as the Central Accounting Office of the Republic would be essential as a regulatory office and informant for all administrative activities involving federal accounting. Lobo and Moraes Junior (1941) highlight that the success of this body as a centralized overseer of Brazilian public accounting would rely on its autonomy, the presence of highly competent technical staff and the establishment of a well-coordinated body of provisions for uniformly regulating accounting practices across all federal offices. According to the same authors, the first two conditions were met through the establishment of the accounting office, and the third was satisfied with the approval of the Public Accounting Code.

On April 29, 1924, the Central Accounting Office of the Republic was officially inaugurated. Accountant general Francisco D'Auria's speech on this occasion illustrates the degree to which public accounting practices were changing at the time (D’Auria, 1953):

This office, which is misunderstood by some and which is a target of systematic attacks, actually facilitates the systematization of regulatory principles of order and clarity in public finances.

What legitimacy will Treasury accounts obtained via chaotic methods and based on the orientation of each individual responsible for administrative bookkeeping tasks offer when a method is adopted or when no regular bookkeeping is carried out? 
While Treasury regulations have always ordered that bookkeeping be conducted via the double-entry system, the truth is that the Treasury has never implemented bookkeeping!

It is unproductive to repeat here the vicissitudes of federal accounting system reform. Obstacles of all types were faced by the double-entry bookkeeping committee. At this point, this most useful initiative would either still exist or routine, unconsciousness and indifference may have suffocated it if champions for the great campaign had not emerged.

Unlike what occurred in 1914 (when the Treasury could not present its situation for the purpose of performing a credit transaction) just two months ago, the federal accounting system received sincere praise from members of the British Mission, and one of its members, one of the most accomplished professional accountants in England, declared that our accounting organization is superior to that of his own country (D’Auria, 1953, p.85).

The reforms that had been instituted in the Ministry of Finance through the centralization of Federal Government financial and asset management reporting were extended in 1925 to tax offices, special offices of the Federal District, the ministries and industrial services, with the Accounting Office receiving a total of 37 monthly balances (D'Auria, 1953). By the end of the 1920s, the Central Accounting Office of the Republic was staffed by approximately 600 employees (D’Auria, 1930).

\section{CONCLUSION}

The definitive introduction of DEB to the federal public accounting system is largely attributable to the creation of the Double-entry Bookkeeping Committee of 1914, which followed the bookkeeping model adopted in 1905 by Carlos de Carvalho of the State of São Paulo Treasury. Although the requirement to implement DEB was enforced by law from 1808, this provision was fully adopted into the federal public accounting system nearly a century later in 1914, when the then Minister of Finance Rivadávia Corrêa, upon request by English creditor bank auditors, discovered that Treasury balance bookkeeping had been delayed by eight years. Efforts were then made to establish the Double-entry Bookkeeping Committee.

The absence of mechanisms for monitoring, controlling and imposing sanctions on noncompliance by law and public administration disinterest in applying this legislation caused the legislation to remain unutilized for over a century. The Double-entry Bookkeeping Committee of 1914 achieved its main objectives, which involved submitting within six months the Federal Government Revenue and Expenditure balance sheet for June 30, 1914 and Federal Government Assets and Liabilities balance sheet for October 31, 1914 and establishing a technical body in the Board of Accounting of the Ministry of Finance responsible for implementing DEB in the federal public accounting system.

The episode that led to the creation of the Double-entry Bookkeeping Committee of 1914 was not unusual in the context of Brazilian history. The public administration once again proved to be reactive to a long existing problem by taking initiative only after being alerted by foreign authorities. At least initially, the committee's goal was not to maintain good practices in public accounting to control the nation's public patrimony and accountability to society but rather to address a time-sensitive requirement to obtain a foreign loan.

A partial parallel with present times could be drawn to recent alerts made by international credit risk rating agencies with respect to accounting maneuvers made by the National Treasury. These maneuvers, also known as "creative accounting," aim to comply with the fiscal primary surplus target of the federal government established via the Budget Guidelines Law. In 1914, alerts from foreign authorities appeared to be more opportunistic than those aimed at improving accounting standards. Risk agencies on the other hand are merely reacting to problems attributable to the use of incorrect practices and to the generally poor state of the Brazilian economy.

Nevertheless, the initiative to reform the National Treasury in 1914 through the creation of the Double-entry Bookkeeping Committee catalyzed changes to national public accounting practices applied at the time. Such changes include the creation of the Public Accounting Code and the establishment of the General Accounting Office of the Republic, which strengthened and ascribed perpetuity to practices adopted in 1914.

\section{References}

Abreu, M. P. (2002). Os funding loans brasileiros - 1898-1931. Pesquisa e Planejamento Econômico (PPE) - IPEA, 32 (3), 515-540. Recuperado de http://ppe.ipea.gov.br/index.php/ppe/article/view/142/77.

Alvará de 28 de junho de 1808. (1891). Crêa o Erario Regio e o Conselho da Fazenda. Rio de Janeiro, Collecção das Leis do Brazil de 1808 Imprensa Nacional.

Aróstegui, J. (2006). A pesquisa histórica: teoria e método. Bauru: EDUSC.
Carnegie, G. D., \& Napier, C. J. (2002). Exploring comparative international accounting history. Accounting, Auditing \& Accountability Journal, 15 (5), 689-718.

doi 10.1108/09513570210448966.

Carvalho, C. (1914). A contabilidade do thesouro de S. Paulo. Revista Brasileira de Contabilidade, 3 (7), 127-131.

Contabilidade fiscal. (1916). Revista Brasileira de Contabilidade, 5 (4), 75-77. 
D’Auria, F. (1925). Apontamentos de historia da Contabilidade. Rio de Janeiro: [s.n.].

D’Auria, F. (1930). Casa do contabilista. Revista Brasileira de Contabilidade, 2 (1), 1-4.

D’Auria, F. (1953). Cinqüenta anos de Contabilidade (1903-1953). São Paulo: Indústria Gráfica Siqueira S/A.

Decisão n. 147, de 26 de abril de 1832. (1875).' Regulamento das Contadorias acompanhado das instrucções para a escripturação das Thesourarias do Imperio. Rio de Janeiro, Collecção das Decisões do Governo do Imperio do Brasil de 1832, Typographia Nacional.

Decreto $n$. 1.335, de 12 de dezembro de 1905. (1905). Institúe no Thesouro do Estado a escripturação em fórma commercial. Diario Official do Estado de São Paulo. 14 de dezembro. Recuperado de http://dobuscadireta.imprensaoficial.com.br/ default .aspx? DataPublicacao $=19051214 \&$ Caderno=Diario $\% 20$ Oficial\&NumeroPagina $=3039$.

Decreto n. 2.807, de 31 de janeiro de 1898. (1900). Reorganisa as Repartições de Fazenda. Rio de Janeiro, Collecção das Leis da Republica dos Estados Unidos do Brazil de 1898, Imprensa Nacional.

Decreto n. 4.475, de 18 de fevereiro de 1870. (1870). Approva os Estatutos da Associação dos Guarda-Livros estabelecida nesta Côrte. Rio de Janeiro, Collecção das Leis do Imperio do Brasil de 1870, Typographia Nacional.

Decreto i. 5.245, de 05 de abril de 1873. (1874). Promulga o novo quadro do numero e vencimentos dos empregados do Thesouro e Thesourarias de Fazenda, e faz outras alterações nos Regulamentos dessas Repartições. Rio de Janeiro, Collecção das Leis do Imperio do Brasil de 1873, Typographia Nacional.

Decreto n. 7.751, de 23 de dezembro de 1909. (1913). Approva o regulamento expedido em virtude do art. 32 da lei n. 2.083 , de 30 de julho de 1909, para execução dos serviços da Administração Geral da Fazenda Nacional. Rio de Janeiro, Collecção das Leis da Republica dos Estados Unidos do Brazil de 1909, Imprensa Nacional.

Decreto n. 13.248, de 23 de outubro de 1918. (1919). Approva o regulamento que altera a organização do Thesouro. Rio de Janeiro, Collecção das Leis da Republica dos Estados Unidos do Brasil de 1918, Imprensa Nacional.

Decreto n. 13.746, de 03 de setembro de 1919. (1920). Dá instrucções para o serviço geral de contabilidade publica, em face da lei n. 2.083 , de 30 de julho, e decreto numero 7.751, de 23 de dezembro de 1909. Rio de Janeiro, Collecçã̀o das Leis da Republica dos Estados Unidos do Brasil de 1919, Imprensa Nacional.

Decreto n. 15.210, de 28 de dezembro de 1921. (1922). Approva o regulamento que altera a organização dos serviços da Administração Geral da Fazenda Nacional. Rio de Janeiro, Collecção das Leis da Republica dos Estados Unidos do Brasil de 1921, Imprensa Nacional.

Decreto n. 15.783, de 08 de novembro de 1922. (1923). Approva o regulamento para execução do Codigo de Contabilidade Publica. Rio de Janeiró, Collecção das Leis da Republica dos Estados Unidos do Brasil de 1922, Imprensa Nacional.

Decreto n. 16.650, de 22 de outubro de 1924. (1925). Organiza definitivamente a Contadoria Central da Republica e approva o seu regulamento. Rio de Janeiro, Collecção das Leis da Republica dos Estados Unidos do Brasil de 1924, Imprensa. Nacional.

Decreto Legislativo n. 23, de 30 de outubro de 1891. (1892). Reorganisa os serviços da Administração Federal. Rio de Janeiro, Collecção das Leis da Republica dos Estados Unidos do Brazil de 1891, Imprensa Nacional.

Decreto Legislativo n. 1.178, de 16 de janeiro de 1904. (1907). Crea os logares de contador e procurador fiscal nas Delegacias Fiscaes do Thesouro Federal, e dá outras providencias. Rio de Janeiro, Collecção das Leis da Republica dos Estados Unidos do Brazil de 1904, Imprensa Nacional.

Decreto Legislativo n. 1.339, de 09 de janeiro de 1905. (1907). Declara instituição de utilidade publica a Academia de Commercio do Rio de Janeiro, reconhece os diplomas por ella conferidos, como de caracter official; e dá outras providencias. Rio de Janeiro, Collecção das Leis da Republica dos Estados Unidos do Brazil de 1905, Imprensa Nacional.

Decreto Legislativo n. 4.536, de 28 de janeiro de 1922. (1923). Organiza o Codigo de Contabilidade da União. Rio de Janeiro, Collecção dạs Leis da Republica dos Estados Unidos do Brasil de 1922, Imprensa Nacional.

Decreto Legislativo n. 4.555, de 10 de agosto de 1922. (1923). Provê as despesas publicas no exercicio de 1922. Rio de Janeiro, Collecção das Leis da Republica dos Estados Unidos do Brasil de 1922, Imprensa Nacional.

Edwards J. R., Coombs, H. M., \& Greener, H. T. (2002). British central government and "the mercantile system of double entry" bookkeeping: a study of ideological conflict. Accounting, Organizations and Society, 27 (7), 637-658.

doi 10.1016/S0361-3682(01)00060-5

Edwards, J. R., \& Greener, H. T. (2003)."Introducing mercantile bookkeeping into British central government, 1828-1844. Accounting and Business Research, 33 (1), 51-64.

doi 10.1080/00014788.2003.9729631.

Fausto, B. (1977). Expansão do café e política cafeeira. In B. Fausto (Org.). História geral da civilização brasileira. Tomo III - O Brasil republicano. Estrutura de poder e economia (1889-1930). (Vol. 1 , pp.195-248). São Paulo: Difel.

Fritsch, W. (1988). External constraints in economic policy in Brazil 18891930. Londres: Macmillan.

Gomes, D., Carnegie, D. G., \& Rodrigues, L. L. (2008). Accounting change in central government - the adoption of double entry bookkeeping at the Portuguese Royal Treasury (1761). Accounting, Auditing \& Accountability Journal, 21 (8), 1144-1184. doi $10.1108 / 09513570810918797$.

Iudícibus, S. (2010). Teoria da Contabilidade. (10 ed.). São Paulo: Atlas.

Jornaes do Rio. (1914). O Estado de S. Paulo. 22 de Julho. Recuperado de http://acervo.estadao.com.br/publicados/1914/07/22/g/19140722 12997-nac-0005-999-5-not-wspxxga.jpg

Lei n. 2.083, de 30 de julho de 1909. (1912). Reforma o Thesouro Federal e dá outras providencias. Rio de Janẹiro, Collecção das Leis da Republica dos Estados Unidos do Brazil de 1909, Imprensa Nacional.

Lobo, U., \& Moraes Junior, J. F. (1941). Departamento administrativo do serviço público - exposição de motivos. Diário Oficial dos Estados Unidos do Brasil. 17 de maio. Recuperado de http://www.jusbrasil. com.br/diarios/2303417/dou-secao-1-17-05-1941-pg-97/pdfView.

Mancini, J. (1978). Estanislau Kruszynski. São Carlos: Editora Ind. e Com. Gráfico "O Expresso" Ltda.

Martins, E., Silva, A. F., \& Ricardino Filho, A. A. (2006). Escola Politécnica: possivelmente o primeiro curso formal de Contabilidade do Estado de São Paulo. Revista Contabilidade e Finanças - USP, 17 (42), 113-122. doi 10.1590/S1519-70772006000300010.

Mascarenhas, J. (1922). Carlos de Carvalho. Revista Paulista de Contabilidade, 1 (1), 16-17.

Miller, P. (1994). Accounting as social and institutional practice: an introduction. In A.G. Hopwood, \& P. Miller (Eds.), Accounting as social and institutional practice (pp.1-39). Cambridge: University Press.

Moraes Junior, J. F. (1921a). Ainda a lei de Contabilidade Publica - I. Revista Brasileira de Contabilidade, 10, 89-93.

Moraes Junior, J. F. (1921b). Ainda a lei de Contabilidade Publica - II. Revista Brasileira de Contabilidade, 10, 101-103.

Prado Júnior, C. (1994). História econômica do Brasil. (41 ed.). São Paulo: Brasiliense.

Sá, A. L. (2008). História geral da Contabilidade no Brasil. Brasília: Conselho Federal de Contabilidade.

Saes, F, A. M., \& Cytrynowicz, R. (2001). O ensino comercial na origem dos cursos superiores de economia, contabilidade e administração. Revista Álvares Penteado, 3 (6), 37-59.

Thesouro Nacional. (1914). Revista Brasileira de Contabilidade, 3 (12), 232-237. 


\section{APPENDIX A}
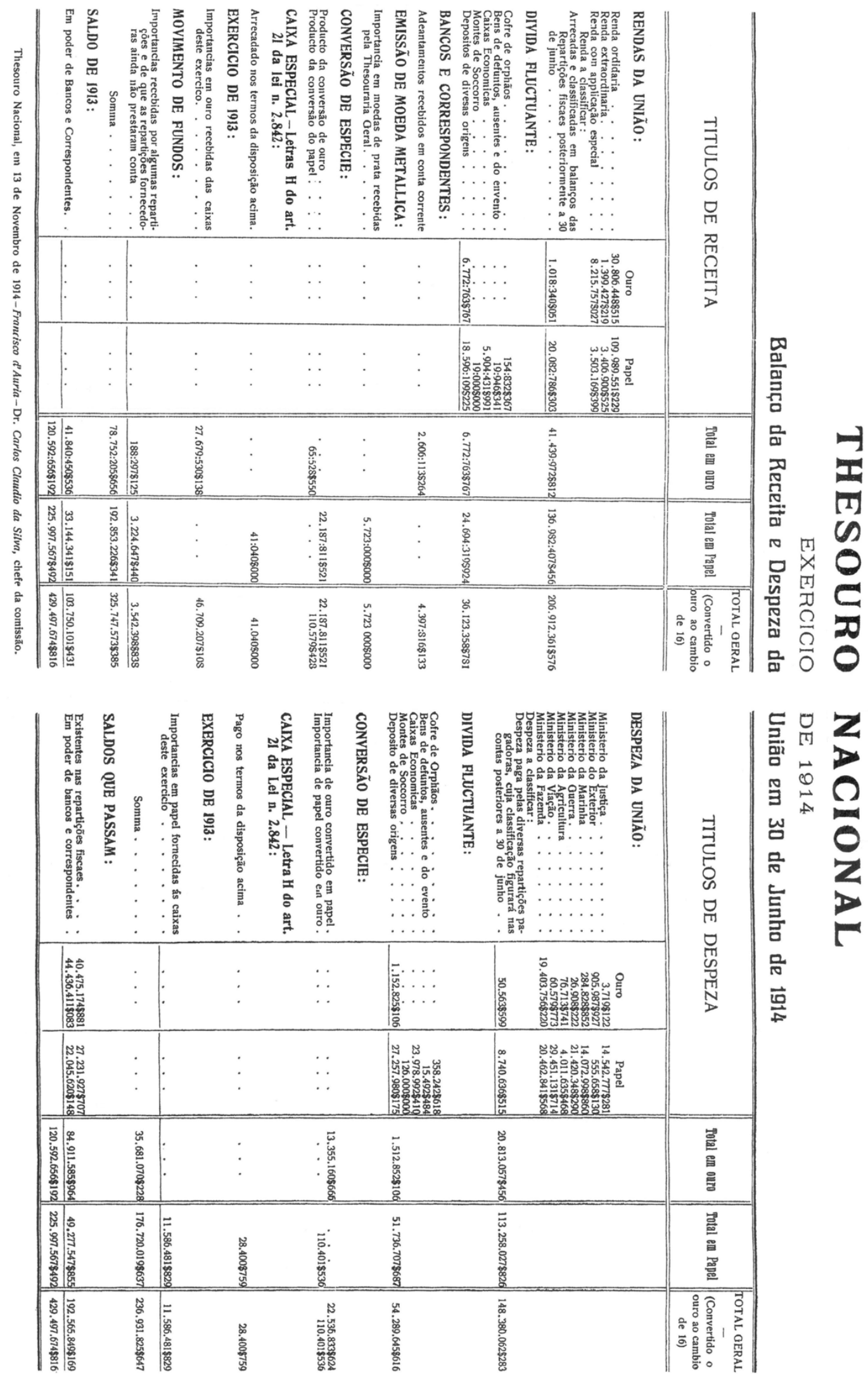

Figure A1 Federal Government revenue and expenditure balance sheet for 06/30/1914. In Thesouro Nacional [National Treasury]. (1914). Revista Brasileira de Contabilidade, 3 (12), 232-237. 


\section{APPENDIX B}

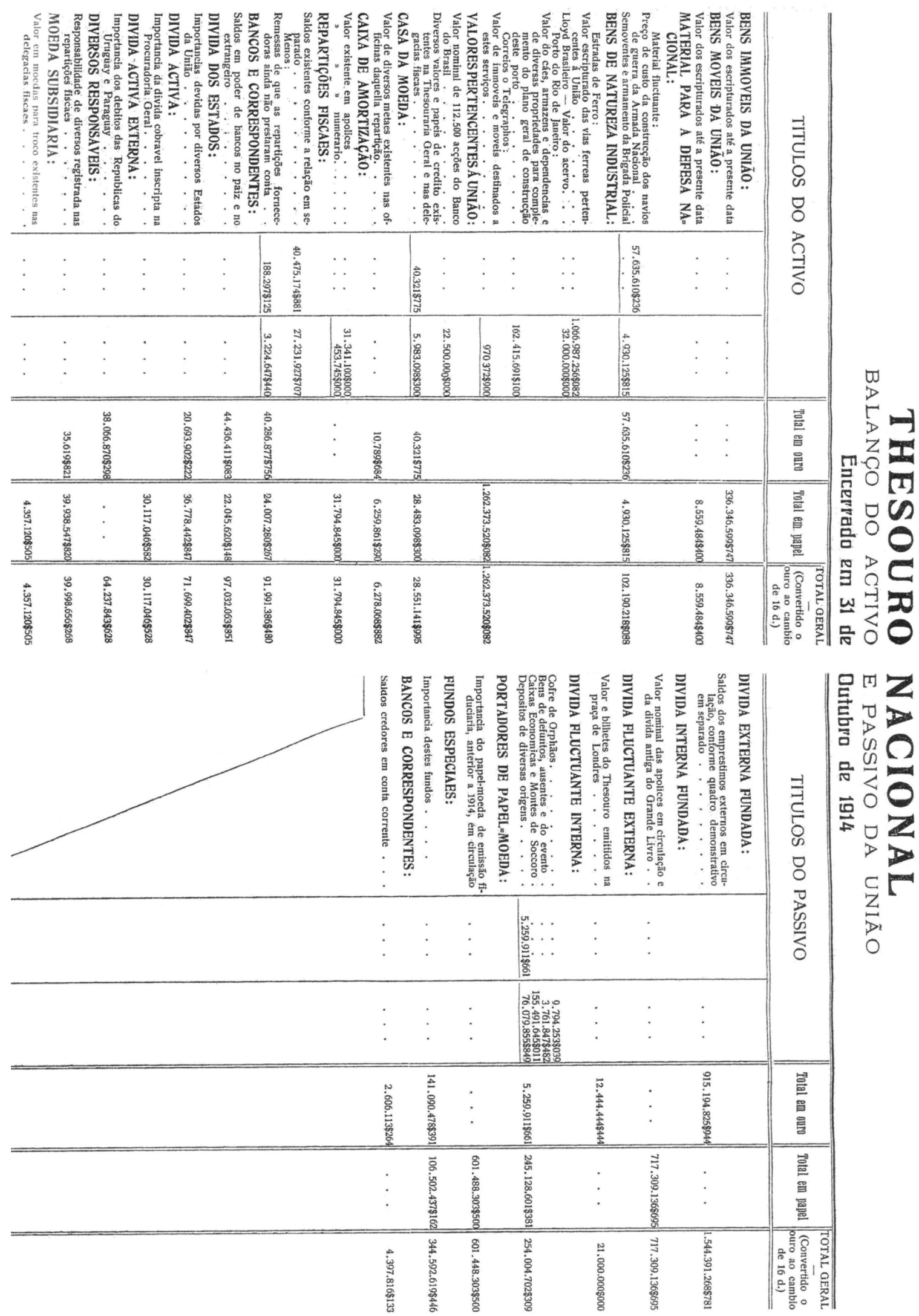

Figura B1 Federal Government assets and liabilities balance sheet for 10/31/1914 (Page 1). In Thesouro Nacional [National Treasury]. (1914). Revista Brasileira de Contabilidade, 3 (12), 232-237. 

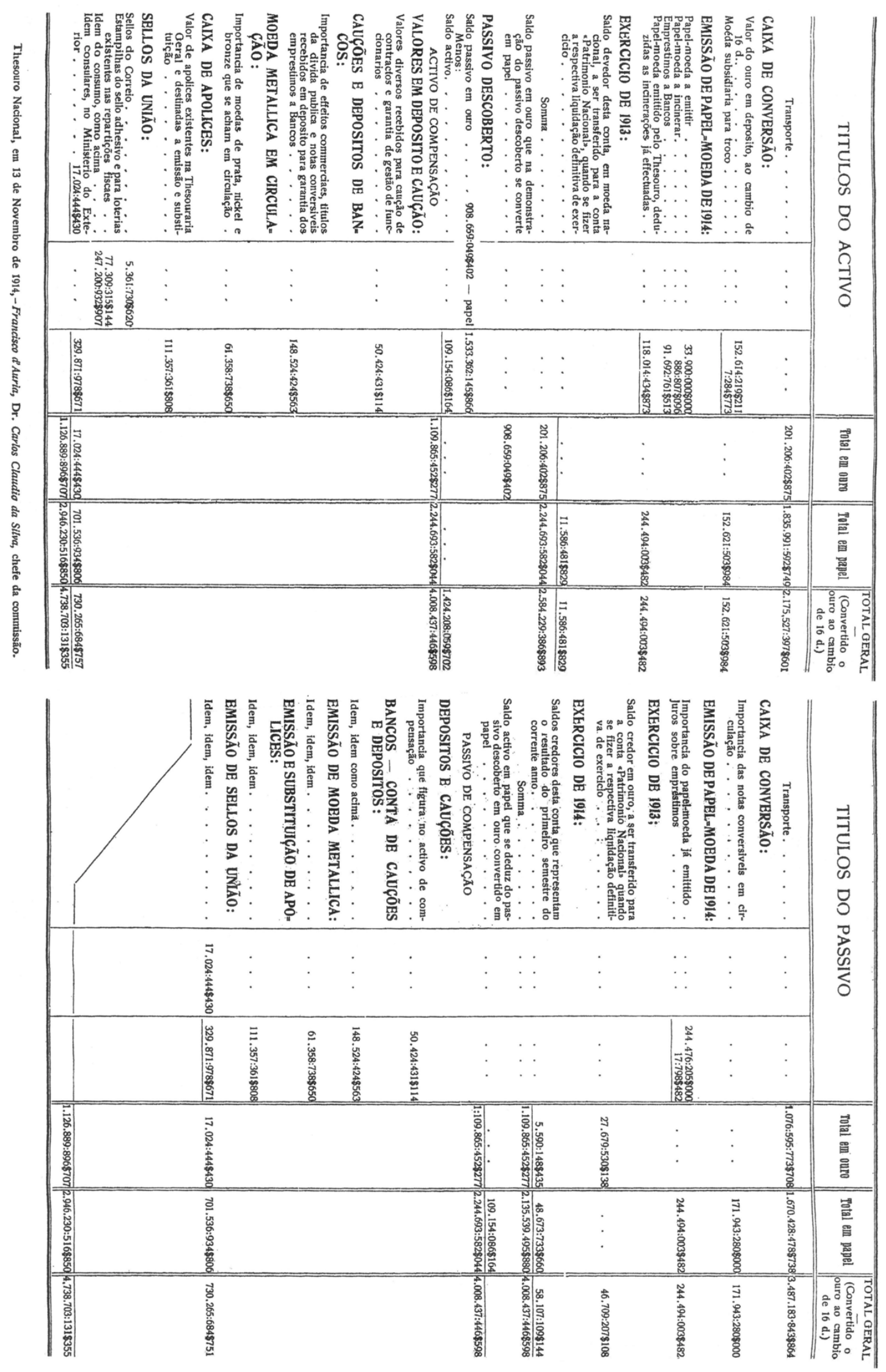

Figura B2 Federal Government assets and liabilities balance sheet for 10/31/1914 (Page 2). In Thesouro Nacional [National Treasury]. (1914). Revista Brasileira de Contabilidade, 3 (12), 232-237. 